DOI: https://doi.org/10.34069/AI/2021.47.11.29

How to Cite:

Cherevko, K., Zhyshkovych, M., Kalyn, R., \& Komarevych, I. (2021). Master class as a leading pedagogical technology in professional improvement of individual performing qualities of singers. Amazonia Investiga, 10(47), 282-292. https://doi.org/10.34069/AI/2021.47.11.29

\title{
Master class as a leading pedagogical technology in professional improvement of individual performing qualities of singers
}

\section{Майстер клас як провідна педагогічна технологія у професійному вдосконаленні індивідуальних виконавських якостей співаків}

Received: October 1, 2021

Accepted: November 29, 2021
Written by:

Cherevko Kateryna ${ }^{115}$

https://orcid.org/0000-0001-5877-4429

Zhyshkovych Myroslava'16

https://orcid.org/0000-0003-3432-2641

Kalyn Ruslana ${ }^{117}$

https://orcid.org/0000-0001-8345-3408

Komarevych Ivanna ${ }^{118}$

https://orcid.org/0000-0002-6940-3794

\begin{abstract}
The purpose of this article is to identify and clarify the pedagogical perspectives of a master class as a leading teaching method that actively influences the process of forming and improving the professional level of singers. The practice of individuating of the educational process in music pedagogy is based on the cooperation of all participants and is aimed at developing musical abilities and individual skills of performers. Master classes play an important role in the improvement of vocalists' professional skills and provide active spreading of performing and pedagogical experience in the world.

This article describes the history of master classes as a special teaching technique in music education, examines and analyzes the peculiarities of conducting vocal master classes by prominent singers: Thomas Quasthoff, Тномаs Hampson, Jerzy Artysz, Ursula Schongals, Elisabeth Schwarzkopf, Montserrat Caballé, Mirella Freni, Joyce DiDonato at.al. Master classes open new ways to raise the level of performer's skills, and thus are the key to further successful development of singer's career. Therefore, the master class is an effective pedagogical technology in the professional growth of individual performing qualities of singers of different ages and different levels of vocal-technique and performing skills.
\end{abstract}

\begin{abstract}
Анотація
Мета даної статті полягає у виявленні педагогічної перспективи майстер класу як провідної технології навчання, що активно впливає на процес формування та підвищення професійного рівня співаків. Практика індивідуалізації навчального процесу в музичній педагогіці основана на взаємній співпраці усіх учасників і спрямована на розвиток музичних здібностей та індивідуальних навиків виконавців. Майстер класи займають важливе місце у вдосконаленні професійних навичок вокалістів і сприяють активному поширенню виконавського та педагогічного досвіду у світі.

У статті простежено історію майстер класів, як специфічної технології навчання у музичній освіті, та розглянуто особливості проведення вокальних майстер класів видатними співаками, серед яких Томас Квастхофф, Томас Хэмпсон, Сжи Артиш, Урсула Шонгальс, Елізабет Шварцкопф, Монсеррат Кабальє, Мірелла Френі, Джойс ДіДонато та ін. Майстер класи відкривають нові шляхи для підвищення рівня кваліфікації виконавців, а відтак, стають запорукою подальшого успішного розвитку кар“єри співаків. Тому, майстер клас $є$ ефективною педагогічною технологією у професійному
\end{abstract}

\footnotetext{
${ }^{115} \mathrm{PhD}$ in Art criticism, Associate Professor, Lviv National Music Academy named after Mykola Lysenko, Lviv, Ukraine.

${ }^{116} \mathrm{PhD}$ in Art criticism, Professor, Lviv National Music Academy named after Mykola Lysenko, Lviv, Ukraine.

${ }^{117} \mathrm{PhD}$ in Art criticism, Associate Professor, Lviv National Music Academy named after Mykola Lysenko, Lviv, Ukraine.

${ }^{118} \mathrm{PhD}$ in Art criticism, Associate Professor, Lviv National Music Academy named after Mykola Lysenko, Lviv, Ukraine.
} 


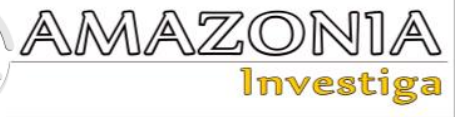

Keywords: master class, singer, performing, teaching methods, pedagogical technology. зростанні індивідуальних виконавських якостей співаків різних вікових категорій та різного рівня вокально-технічної i виконавської підготовки.

Ключові слова: майстер клас, співак, виконання, методи навчання, педагогічна технологія.

\section{Introduction}

The actuality of searching new pedagogical approaches in education is an important component of modernity. However, regardless of the specifics of each one of the branches, the efficiency of these approaches is aimed at humanizing this process, in which the central place is occupied by a person gaining some knowledge. The leading role in this process is the activation of individual's cognitive abilities, resulting in the accumulation of skills and experience. Especially brightly this approach is represented in the field of art education, which is based on century-old accumulated teaching methods.

The specificity of music education consists in an individual approach to teaching, where the teacher-mentor plays a great role. The practice of individuating of the educational process in music pedagogy is based on the cooperation of all its participants and is aimed at deepening the professional skills of musicians and improving their individual performing qualities. In this sense, their participation in various master classes is important as it is one of the special forms of learning, which forms creative environment and cooperation of all participants, and thus - "the opportunity to compare different views, debate different methods, discuss technical, interpretive... and general performing problems" (Popovych, 2010, p. 149).

\section{Theoretical Framework or Literature Review}

The master class is one of the singular forms of improving practical skills of professional musicians in the modern sociocultural educational space. The value of this form of training is that master classes are conducted by leading specialists who have a high level of professionalism. The role of the master class as one of the leading modern pedagogical technologies in various fields of education is studied in the works of Andreeva J. (2005), Chernega E. (2009), Rotmirova E. (2016), at.al. A separate group of works consists of the research of the master classes in the field of art. The article of Bobryashova O. (2011) considers a master class as one of the pedagogical technologies in the training of designers; the articles of Lomova E. (2018) and Hama S. (2012) reveal the importance of a master class in high school in the training of teachers of fine arts. Other works are devoted to the role of the master class in music education. Breeze N. (2014) considers it in the process of transforming teaching and musical learning. Hanken I. (2010; 2015) points out the importance of listening in master class and outlines its benefits and perspective. However, issues related to the specifics of vocal master classes are poorly studied and require deeper understanding and analysis.

The purpose of this article is to identify and clarify the pedagogical perspectives of the master class as a leading teaching method that actively influences the process of forming and improving the professional level of singers.

\section{Methodology}

The methodology of the research is determined by the specifics of the problem and consists of a complex of scientific methods: source study when studying the master class as a teaching technology, historical - when considering the history of the master class, theoretical - when analyzing the characteristics and structure of classes, comparative and empirical - when considering the master classes of the leading singers and vocal teachers, which make it possible to identify the master class as a leading pedagogical method in the professional development of performing qualities of singers.

\section{Results and Discussion}

The master class is one of the ways to share pedagogical experience, which contains a detailed and practically tested author's methodology. Thus, according to researcher O. Chernega (2009),

This is a unique form of "building" professionalism. But, like any other 
organizational and practical form of work with professional experience, it requires "grinding" and improving to be ready for its use by the "transmitting" party and the party actively "perceiving" this professional experience (p. 96).

At the same time, the master class remains an open pedagogical system that promotes the formation of new ways of developing teaching methods. Therefore, it is important during such classes not only to present the methodology, but also to discuss and demonstrate the practical using of its main principles aimed at overcoming certain performing difficulties. This process is common to all participants of the master class. Thus, there is not only the transfer of author's pedagogical idea, but also its practical mastering. The formation and development of author's methods is a complicated phenomenon, which is based on the using of well-known didactic methods, as well as own experience of pedagogical practice and searching of individual approaches for working with different categories of participants.

The importance of the master class lies in the effectiveness of the transfer of knowledge and skills, exchange of experience in learning and education, the central point of which is the demonstration of the original methods of mastering a certain material by the active role of all its participants.

Finally, the master class is a special form of teaching, which is based on "practical" activities of showing and demonstrating a creative solution to a certain cognitive and problematic pedagogical task.

Thus, the above-mentioned peculiarities of the master classes allow us to identify their characteristic features. The master class demonstrates completely new approaches to the "philosophy" of teaching and lets us organize the creative process to solve certain performing difficulties, provided there is a friendly environment where all participants actively cooperate for a common goal. After all, setting a problem and solving it through playing different situations is the basis of the master class, which reveals the creative potential of both the master and the participants.

We should remark that the master class is not one of the latest teaching technologies in music pedagogy. The practice of such classes has a long history. Thus, the first classes in order to improve the professional level, which were built on the principle of mutual cooperation and based on previously gained knowledge, took place in ancient Greece. Sophists' system of education can serves as an example. It contained several forms of teaching.

Among them there were speeches of the sophist by themselves, in which they demonstrated their skills (epideictic speeches), and training workshops in which pupils practiced their skills. The second method of teaching includes verbal battles and polemical disputes, which for their part are close to the practice of court appearances (Wolf, 2018, p. 290).

However, one of the special forms of teaching, which can be regarded as the master class, is the demonstration of Sophists' own mastery in front of their pupils, which took place in the presence of the public. During such classes, the teacher always analyzed in detail the performances of their students. Thus, the first master classes conducted by the sophists were based on the knowledge and skills of students that they acquired in previous years of studying.

The next stages in the development of the teaching practice of the master class can be considered the activities of Renaissance artists and concert musicians of the Baroque. The method of teaching playing the violin, described in the letters of the famous violinist Giuseppe Tartini, containing a description of the techniques of playing the violin, is considered to be significant (Tartini, 1913). These letters were addressed to Laura Sirmen (Lombardini), who studied at the Ospedale dei Mendicanti in Venice at the expense of Tartini. The content of the letter of May 5, 1760 indicates that the next classes would take place in the form of a master class.

However, the first master classes, in the modern sense, belong to the famous pianist and composer Franz Liszt. It was Franz Liszt, who from 1869 to 1886 conducted classes for professional musicians in Weimar, which included all components of the master class, namely: demonstration of their own professional skills, working out difficulties in performance on the example of musicians' skills and in the presence of an audience. Liszt's master classes were held for a large number of participants (10-20 people), who had to prepare their works in advance for practicing during the class. Such master classes lasted about two hours.

Generally, during the master classes students played works by heart, and Liszt gave them advice how to perform them. Liszt's method of teaching was unique. He explained how to 


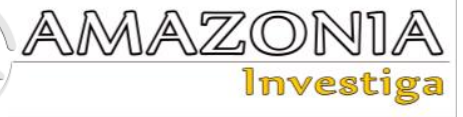

perform some moments in the work, but immediately replaced the participant, if the performing of previous one did not satisfy him. In the event that several students one after another could not complete the task correctly, Liszt showed personally how to play.

According to Liszt's students' memoirs, we can get some idea of how the master class took place. Arthur Friedheim describes the lesson as follows,

In his master classes, Liszt would talk about the work being performed, discussing its relation with other music by the same composer, and with previous and contemporary works. He would point out the form and proportions of the piece and its moments of climax. All playing was done from memory, and his pupils practiced six or seven hours a day (Gervers, 1970, pp. 390-391).

In Liszt's master classes there was always competition between its participants, because public performing motivated students to compete. It became the key to the success of his students, who aimed at more professional and perfect performances. Usually in the master class pianists played various works, the notes of which they left on the piano before class. Performing of a different program was aimed at ensuring that each of the students could get acquainted with the features of a particular work before working on it. Such teaching approach became the way to success of each participant. However, the main advantage of this form of training is the ability to perform in front of an audience and gain confidence during this process.

Liszt's master classes were not aimed at solving certain technical difficulties of performing; they focused on the interpretation of the work, its figurative world, sound quality and various nuances. One of the most important roles of Liszt's teaching is the close connection between music and poetry, in which a poetic text became a stimulus for the interpretation of the figurative world of a piece of music.

This belief may explain why he took so little interest in technical details and so much in the expressive nuance that made music able to say what words were incapable of conveying. He acknowledged the importance of virtuosity, but in his mature view he did not consider that it should be put on show (Gervers, 1970, p. 385).

In fact, his students learned by imitating the great technique of Grand Master.
Liszt's methodology was aimed at an individual approach to the interpretation of the work, when each student had an opportunity to create their own figurative and sound world. He said, "Only a picture of the image and the body will find its own way to project it" (Walker, 1996, p. 232). The master did not impose on students the principles of interpretation of the work, but encouraged them to create their own interpretive versions, thinking that, "There are no great teachers, only great pupils" (Walker, 1996, p. 232).

Before each performance, Liszt analyzed the work in terms of style, genre specificity and special creative style of the composer. An important aspect of the classes, as mentioned previously, was that the students performed in front of an audience. Therefore, the classes conducted by Liszt corresponded to the specifics of the master class, because they contained the features inherent in this teaching form.

The history of the master class demonstrates one of its main features, namely, the ability not only to present but also to pass on author's methodology. Of course, the traditional character and a certain conservatism of music pedagogy lead to the use of established pedagogical principles, enriched by own approaches and techniques that help to solve certain performing problems. The originality of these approaches and their practical demonstration determine the level of author's professionalism. Therefore, conducting a master class is aimed at solving a problematic pedagogical task by applying the author's guidelines and with all members' active participation.

Due to these features of the master class as one of the leading forms of developing professional skills in music pedagogy, we can identify its main criteria:

- based on established musical and pedagogical traditions, the master class reveals new approaches to solving performing problems;

- the master class is not an unilateral process, as it involves all its participants. Of course, the active participation of all presents is one of the conditions defined by the master themselves;

- during the master class, the difficulties are solved not only through the creative potential and skills of the author, but also through the demonstration of various ways of getting over them; 
- ways of solving performing problems are in no way imposed, but only suggested; usually their effectiveness is proved in practice;

- the main task of the master class is the moment when the participants master the solution of a pedagogical problem using the suggested methodology, which will contribute to further self-improvement of their skills.

Therefore, the organization of the master class is a rather complicated process, with predetermined tasks, aimed at effective achievement of the goal. Of course, the way of improving professional skills is always related to solving certain technical and performing problems. For this reason, the ability to respond quickly to them and solve them qualitatively today determines the level of professionalism of the teacher. There is no doubt that the master class as an educational form embodies innovative approaches. However, this innovation is the result of long professional experience in working out the performing aspects of the problems. As a result, there is a crystallization of a specific algorithm of actions aimed at solving certain technical and performing problem.

An important factor in the process of carrying out the master class is the ability to react quickly and systematically to those problems that arise as a result of individual performing skills of its participants. We mean the ability of accurate correction of performer's skills for the sake of achieving the goal. Therefore, the correct and timely direction of the participant is the key to the success of the presented methodology, which "works" in practice. Thus, the author of the master class, relying on a well-established scientific and methodological basis, should use the system-target understanding of the advanced type. Only under such conditions will the methodology of the author be presented consistently and comprehensively.

As was mentioned above, the peculiarity of the master class is mutual cooperation, because within such classes there is not only a presentation of author's professional experience, but also the skills of all participants. And it is the last ones who not only perceive the presented methods, but also evaluate them. The practical application of the performing methods offered in the master class is a determining factor that contributes to development and improvement of performer's skills. It is worth noting that the formation of new skills always takes into account individual approaches and focuses on the level of their professional skills. This is the main problem of organizing and conducting the master class. The outstanding Ukrainian pedagogue V. Sukhomlynskyi said,

The true pedagogical creativity is characterized by the features of research, creative consolidation of one's own work. The most likely to become an educator is the one who feels like a researcher. If you want pedagogical work to be joyful, put every teacher on a happy path of research (Kirichenko \& Kovganych, 2019, p. 34).

Thus, the problem of scientific and methodological competence of its participants comes to the forefront in the process of conducting a master class. Therefore, the "flexibility" of author's thinking and ability to react quickly according to the needs of the participants are the guidelines that result in a successful demonstration of the presented methodology. That is why the master class is always a very interesting organizational and pedagogical process, unique in its kind, because it depends entirely on the practical experience of the participants. In the process of the master class, they not only improve their practical skills, but also receive an "incentive" to reach the heights of true professionalism through selfimprovement. The result is the desire to selfdetermined professional excellence.

\section{O. Bobryashova (2011) defines this process as,}

The axiological significance of this technology lies in the fact that the exchange of values forms attitudes toward knowledge of the surrounding reality. This stage is the initial phase of orientation, the process of growing of each individual into the world of spiritual culture. The received impressions generate satisfaction or dissatisfaction of the person, pleasure or sadness, excitement or depression, namely they are followed by feeling (p. 171).

Thus, the main task of the master class is to promote professional and self-developmental approaches. Therefore, the whole process of conducting a master class should be aimed at forming the need for independent work and the achievement of the goal. Participant's confidence in the successful solution of the problem is a powerful incentive for further professional development.

The peculiarity of master classes for vocalists is that it can be held in two formats - group and individual. However, in each of them, the presence of participant-spectators is important, not only to observe the process, but also to take 


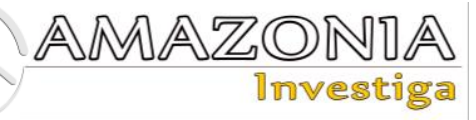

an active part in the discussion of the presented methodology. In this way, the master can maintain a balance between the professional skills of the performer and their psychological and personal qualities, such as emotionality, type of character, temperament, thinking, etc. According to these qualities, the master, in order to achieve the goal of the master class, creates a string of logical tasks, which leads to a successful, practically approved result.

The moment of reflexivity is important in the process of conducting a master class - appearing the psychological and emotional state of the participants, which influences the process of the class and is important for author's further work. The master class identifies and corrects problems in participants' professional skills, reveals ways of solving technical performing problems, and consequently provides direction for further independent work to improve their own professional skills. However, the adjustment process is built on the formation of creative atmosphere, democratic interaction of all parties - the master and the participant. Such an approach is possible only because of the presence of such characteristics as sociability, intelligence, goodwill, generosity and willingness to solve any problematic situation.

Due to the fact that the "manner" of conducting a master class depends on many factors, such lessons contain some differences. It is understood that both the presentation of author's methodology and the ways in which it can be applied in practice will depend on the professional capabilities of the participants. Therefore, in the process of conducting a master class, the author gains some social and communicative experience and their methodology is improved and practically tested in specific conditions.

At the present stage of the development of music art, master classes have in general become one of the most popular and required forms of teaching, as they are aimed at improving the practical skills of musician-performers. Not only participation in the master classes, but also their viewing on the Internet allows the participants to broaden their worldview and influence the further process of their self-improvement. An important part of this process is the exchange of experience between representatives of different national performing schools. Thus, we can talk about the globalization of art education.

The activities of the British non-profit organization the Masterclass Media Foundation are connected with recording master classes of the famous contemporary musicians. The organization contains an archive of the master classes, which is valuable for future generations of musicians. Moreover, in today's conditions, their availability through digital media and the Internet seems to be important. The company cooperates on a regular basis with a number of renowned musicians, including pianist András Schiff, violinist Maxim Vengerov, and conductors Bernard Johan, Herman Haitink and Kurt Masur, multi-percussionist Evelyn Glennie, violist Yuri Bashmet, vocalist and bass-baritone Thomas Quasthoff at.al. (The Master class media foundation, n.d.).

Analyzing modern vocal master classes we can identify their main structural components. The first stage of the master class is a theoretical presentation of author's concept. The importance of this stage lies in the accessibility and logical presentation of the material, while noting its novelty. The next and most important stage of the master class is the organization of practical application of the presented methodology. It is the correct organization, purposefulness and consistency in the performing of individual tasks that is the key to achieving successful results. At the final stage of the master class, each participant demonstrates their own achievements, which are the result of practical mastering of actor's technique. Thus, the success of the master class, as has already been mentioned, lies in author's mental flexibility and their ability to quickly correct the performing problems of each of the participants. Depending on participants' individual capabilities, the ways to achieve the results can be different.

Performing master classes are classified according to several criteria: instrumental master classes are divided by types of instruments, vocal - by type of voice. The other principles of division are the direction of master classes depending on their purpose and objectives. That is why master classes are often focused on stylistic, genre peculiarities of performance, on characteristic features of the interpretation of certain works, their performing difficulties, the manner of sound production, the problem of reproduction of the figurative world of the works, and etc.

We will design further material on the analysis of the master classes conducted by well-known European and world-class singers and educators.

For example, the famous singer Thomas Quasthoff conducts master courses called the 
Quasthoff Method. The name of the course is already clear that it is composed of a series of master classes and is aimed at discovering the secrets of singer's vocal mastery, as well as passing on their own professional experience. This course is designed to deepen the professional training of singers. As stated on singer's official website, "Rather than only using the shorter and more usual masterclasses, Thomas Quasthoff's master courses are more demanding, run over several days, but are key to how Thomas is able both to inspire and train the great voices of the future "(Thomas Quasthoff, 2020). His master classes are held exclusively on stage and are open to the audience. As a rule, these classes are based on the classical repertoire and are aimed at solving a number of performing and interpretive tasks.

American baritone Thomas Hampson is a famous vocalist-teacher who has been conducting master classes for young singers for many years. In particular, his first master class was held at Manhattan School of Music in 2007. These master classes are organized annually for talented singers: bachelors, masters and doctoral students under the aegis of the Hampsong Foundation and are focused on different aspects of performance, from musical expression to work on vocal technique, and scenic mastery. Thomas Hampson's master classes are centered on performing works from different stylistic eras: Mozart, Rossini, Debussy, Bernstein, Schubert, Schumann, Strauss and Mahler at.al.

The problems of interpreting romantic vocal chamber music of different national schools are revealed in the master classes of the well-known Polish singer, long-time soloist of the Grand Theatre and National Opera in Warsaw, Jerzy Artysz. As a great performer, he spent a great deal of time working with the vocalists of the Grand Theatre. Also Jerzy Artysz organized a series of master classes for young professional singers. In the process of their carrying out the singer individually approached each participant, very quickly adjusted the sound of performer's voice, pointing out the mistakes, and, at the same times, the ways to solve them. Therefore, his master classes are distinguished by dynamism and flexibility of overcoming performing difficulties. The maestro paid great attention to articulation, focusing on the pronunciation of vowel sounds. However, he prioritized the naturalness of the voice, its flexibility and expressiveness. In addition to working on the technique of performance, the maestro paid a lot of attention to the interpretative aspects, following quite classical canons of the sound of operatic arias. Professor Jerzy Artysz, "... relying on his considerable theoretical knowledge and practical experience, he was respectful and tolerant of young singers, worked very actively, delivered his instructions clearly, convincingly, figuratively and very warmly, which created an atmosphere of goodwill and trust" (Zhyshkovych, 2018, p.66).

The master classes of Professor Ursula Schongals from the University of Music and Theatre "Felix Mendelssohn Bartholdy" Leipzig, focused on the special performing features of German vocal chamber music of the Romantic era, are well known today. An important place at the master class of the singer is the work on the figurative content of the piece of music. Based on this, she reinterprets the musical intonation and creates each individual vocal phrase. During the performance, Ursula Schongals points out the special importance of clear pronunciation of each word of a romantic song, because it carries a semantic load that affects the overall figurative meaning of the song. Consequently, to create the image of the song, certain sound "tones" are used. In this way, Professor Schongals shows the close connection between the figurative content of the poetic text and music. Thus, detailed work on the image, on the ability to "get used" to it, helps to reproduce the subtle nuances of a piece of music. Note that while working on the interpretive aspect, the professor pays great attention to the performance not only of the vocal part, but also of the piano part. During the master class Ursula Schongals, according to performer's individual characteristics, tries to find special colors of voice sound necessary to reproduce the emotional mood of the work. The specifics of the construction of each vocal phrase depend on the coloring of the lyrics.

The analytical mindset of Professor Schongals is especially noteworthy. While in 2011 in Lviv (Ukraine) at the Lviv National Musical Academy named after Mykola Lysenko with master classes, she took part in the international conference and made a report on "The multiplicity of modern interpretations of the song Ich grolle nicht from the series by R. Schumann The Poet's Love," based on a comparative analysis of four interpretations of one of composer's most famous masterpieces.

Renowned German singer Elisabeth Schwarzkopf was actively engaged in conducting master classes for young vocalists since the end of her vocal career in the 1980s. Each of her master classes revealed her own way of dealing with the work. These master classes were 


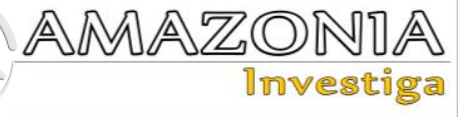

attended by a large number of participants, so we can learn about them from the feedback of their participants. Elisabeth Schwarzkopf's master classes were held in the usual format: one participant performed a work in front of an audience. During the performance, the singer stopped the participant and pointed out the mistakes and shortcomings of the sounding. It is important that she showed how to avoid mistakes and the correct sounding of a certain musical phrase.

Elisabeth Schwarzkopf was often quite harsh in her comments. She paid attention to every detail: proper breathing, phrasing, pronunciation. Her method of work consisted in a detailed elaboration of a musical phrase by repeatedly practicing it. With each new version of sounding, she pointed out shortcomings and made corrections, thus trying to achieve perfectly correct sounding. One of the participants of the master class, Olga Buzina, mentioned,

I have never met more intelligent singer: every gesture, head turn, every posture and breathing was perfectly thought out ... Schwarzkopf's diction was perfect, she put words into a clear semantic line, a complete phrase, it was not a case of singing a beautiful melody and narcissism at a successful top note, I never saw the prima expressing the emotions of the heroine with an artificial grimace. Elizabeth Schwarzkopf had a divine voice from the mind (Stolyarova, n.d.).

It is important that most of singer's master classes are devoted to the problem of interpretation of Hugo Wolf's vocal works. Elisabeth Schwarzkopf's performance not only popularized Wolf's work, but also revealed the peculiarities of the interpretation of his works. Composer's songs are known to be difficult both to perceive and perform.

The artist said that Wolf's songs opened to her a new, quite peculiar world of musical and poetic images, which required from the performer an extreme sensitivity to the word, the manner of their pronunciation, the richness of their vocal coloring to mark a new semantic emphasis, psychological nuance, in which every curve of vocal line in composer's works is closely combined (Timokhin, 1974, p. 109).

The difficulty of performing Wolf's works lies in the declamatory nature of his melody. So, an immersion in the figurative world of his music occurs through the poetic text. It was the poetic text which became the basis for the creation of an individual musical form of its realization. The specificity of the melody of Wolf's vocal works is connected with the inner melodiousness of the poetic text.

Therefore, Elisabeth Schwarzkopf, in her master classes dedicated to Wolf's works, demonstrated her own interpretation of this music. At the heart of singer's performance is a special performing manner, based on the most expressive presentation of each word. This served as one of the guiding principles of her master classes. Lindsay Feldmeth (2012) - a professional opera singer, wrote,

Frau Schwarzkopf was famous for making caustic comments at her master classes. She could be pretty brutal with her students. I was thinking about her reputation when I climbed onstage to sing Hugo Wolf's Schlafendes Jesuskind for her. The song opens with the words, "Sohn der Jungfrau, Himmelskind!" But it took me eight tries to get to the word "Himmelskind", because Frau Schwarzkopf kept interrupting me. A couple of times, I hadn't even made a sound before she yelled, 'Nein!'.

Master classes of the famous Spanish singer Montserrat Caballé were held annually and gathered a large number of young vocalists. These classes demonstrated the performer's special approach to singing technique, so they were conducted in a specific form. Since one of the main performing problems of vocalists is breathing, Montserrat Caballé emphasized this aspect. Although some participants had no breathing problems, the singer still sought to teach them how to manage their breathing processes consciously. Therefore, as a rule, each lesson began with ten-minute breathing exercises, performed by participants on the floor: they lay on their backs and held special discs on their stomachs, which put additional pressure on the diaphragm. In this way, the vocalist, with the help of muscle resistance, begins to feel exactly how the muscles should work and which of them should be involved in proper breathing. Consequently, a conscious and correct work of singing breathe is developed. During these breathing exercises, Montserrat Caballé showed how to "economically" use their own breathing resource, holding their breath for a while.

The next stage of the master class was an audition for the participants, each of whom performed only one aria of their own choice. During participants' performances, the singer analyzed every detail. In addition to correct sound formation, she always paid attention to the figurative content of the work and its correct 
reproduction. Montserrat Caballé repeatedly stated that the main thing is not only to sing the notes; you need to "pass" the work through yourself. Thus, Caballé's master classes focus on adjusting breathing technique, singing technique, and creating the correct figurative and emotional coloring of the work.

The master classes of the Italian opera singer Mirella Freni became important in the careers of many performers. Since 2004, she was actively engaged in pedagogical activities, teaching young vocalists. It was for this purpose that the singer and her husband founded the Centro Universale del Bel Canto $(\mathrm{CUBeC})$ in Vignola near Modena. Mirella Freni conducted lessons for center's students exclusively in a master class format. One of her students Lindsay Feldmeth (2012) mentions,

That's why I was thrilled to discover that Mirella Freni teaches her own students in a "master class" format. When I moved to Italy to study with her in 2005, I did not realize that my "classroom" would be a sixteenth century palace! On the day of my first lesson, I climbed up a magnificent spiral staircase to a large chamber with painted ceilings, where sixteen young singers were singing arias for each other while Signora Freni made suggestions.

While listening to the performers, Mirella Freni always paid attention to the way the sound was formed, pointing out that it was necessary to sing freely, without muscle clamps, and the voice should be natural.

English singer and educator Richard Berkeley agrees with the Italian diva, saying,

Being a performer is great courage, because you constantly have to bare your soul to the audience. You cannot afford to put a sheet of paper between your eyes and the eyes of those who listen to you. Be emotional, and you'll discover abilities in yourself that you didn't even know you had. Sing the way you talk in everyday life (Ben, 2013, p. 113).

Berkeley's master classes paid great attention to both the manner of singing and acting. His technique is based on the leading principles of Italian bel canto. In master's opinion, the natural sounding of the voice is based on the inner freedom of the performer, the sense of comfort and ease, and the recipe for success of the vocalist on stage is a close connection of voice, body, emotions, and intellect. Berkeley's method is aimed at using relaxation techniques and natural activation of inner resources of the participants. To do this, he uses a variety of modern vocal and breathing techniques and exercises aimed at developing vocalist's acting skills. Based on this, the singer reveals ways to create his own original performing style and identifies ways to overcome emotional barriers in performance.

The tradition of Italian bel canto singing is continued by the famous singer, "Gestalt therapist" at the Norsk Gestaltinstitutt in Oslo, Carlo Allemano. His performing creativity is focused on works from the Baroque era. Allemano's vocal method is based on the old traditions of the Italian vocal school. At his master classes, the singer pays a lot of attention to different performing aspects: the high position of the sound, the proper deep breathing, the expressiveness of speech, etc. He assigns the leading role in the lessons to performer's inner emotional state, convincing reproduction of the figurative content of the work, and its stylistic interpretation.

Today Joyce DiDonato is best known for her master classes. Joyce DiDonato is not only an active performer but also carries out many classes for young vocalists. In recent years, the singer has given master classes at Carnegie Hall, the Royal Opera House - Covent Garden, the Guildhall School of Music \& Drama, and The Juilliard School.

Young artists have a lot to offer the world through their artistry. Their respective journeys, beliefs, and passions all inform the direction their career will take. They need guidance and encouragement, and through master classes and other in-depth educational opportunities these artists are offered the chance to explore their creative potential in a collaborative environment (Joyce DiDonato, 2019).

At the core of singer's methodology is the belief that singing is a process. For this reason, Joyce DiDonato holds master classes over three days, during which the audience can observe how the manner of participants' performance changes. Each of the young singers, as a rule, focuses on vocal technique, rather than figurative reproduction of the work. However, the singer explains that "technique is not what's going to make your audience cry" (Courtois, 2015). Therefore, she advises performers to focus on the temper of the personage and their musical embodiment, just those traits that will help reproduce the mood and personality of the character. In this case, the vocal technique seems 


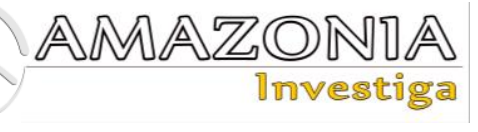

to "take a back seat", becoming quite natural. Before performing each of the arias, Joyce DiDonato gives a detailed analysis, noting the most striking moments. "Thus, DiDonato's process: once one has interpreted a line, they have to render it and make themselves invisible by making the technique and even the music disappear" (Courtois, 2015). The singer pays great attention to the interpretive aspects, working carefully on them: numerous repetitions of one phrase are accompanied by her comments, which "guide" the participant. That is why DiDonato points out the importance of every detail contained in the musical text. She emphasizes that you need to perceive music only through your own feelings. Joyce DiDonato is called "a model of singing in which all the components of the art form - technique, sound, color, nuance, diction - come together in service to expression and eloquence" (Schweitzer, 2013).

\section{Conclusions}

In summary, the master classes play an important role in the formation and improvement of the professional skills of performers and contribute to the active spreading of performing and pedagogical experience in the world. A special place is given to the vocal master classes, which contribute to the development of the performing creativity of young singers. It is through the communication with the prominent opera performers that they are able to learn part of their mastery, identify their own shortcomings and receive advice on how to overcome them. The basis of this pedagogical technology of teaching vocalists is the moment of "live" communication, imitation and inspiration of the manner of singing. Under such conditions, the formation of vocalists' artistic manner, the shaping of their outlook, and understanding of all the "nuances" of vocal art take place.

The leading role in conducting the master class is taken by the teacher, whose high professional skills are the key to the successful dissemination of their own experience. However, the ways to achieve positive results are individual not only for the master's work, but also depend on the capabilities of the participants. The featured master classes of the outstanding singers are aimed at solving both purely vocal and general performing problems. The characteristic feature of this form of classes is the creation of a welcoming atmosphere and an individual approach to each participant, taking into account their performing characteristics.
The master not only explains and comments on performing shortcomings, but also demonstrates ways of avoiding them, which becomes the impetus for further independent professional improvement. Consequently, the emotionality of the teacher, the persuasiveness of the technique and confidence in the positive result will have a psychological impact not only on the participant, but also on the audience. In this way, master classes offer new perspectives on the growth of performer's skills and become the key to furthering performer's successful career. We can therefore convincingly consider the master class as the leading pedagogical technology for improving the individual performing qualities of singers of different ages and different levels of vocal and technique skills.

\section{Bibliographic references}

Andreeva, J. (2005). Master-class as a form of practice-oriented training of specialists in the field of advertising. Alma Mater: Bulletin of the Higher School, 11, 31-34.

Ben, G. (2013). Richard Berkeley's Master Class or Recipes for the Science of Singing from a British Professor. Proscenium: theatrical Journal, 1-3 (35-37).

Bobryashova, O. V. (2011). Master class and creative workshop as pedagogical technologies of active training of future designers. Bulletin of the Orenburg State University, 11, 169-175.

Breeze, N. (2014). MasterClass in music education: transforming teaching and learning. Music Education Research, 16(2), 223-225. https://doi.org/10.1080/14613808.2014.8 95099

Chernega, O. A. (2009). Formation of pedagogical skills of the future engineerteacher by means of a master class Higher school. Humanization of the educational process, 47, 92-98. Retrieved from https://ddpu.edu.ua/images/naukvid/gnvp/ gnvp_47.pdf

Courtois, T. (2015, March 6). Joyce DiDonato: Master Class at Carnegie Hall. Operaonline. Retrieved from https://www.operaonline.com/en/articles/joyce-didonatomaster-class-at-carnegie-hall

Feldmeth, L. (2012, April 6). Inside the master class. The Globetrotting Soprano. Retrieved from https://globetrottingsoprano.com/2012/04/ 06/inside-the-master-class/

Gervers, H. (1970). Franz List as pedagogue. Journal of research in music education, 
$18(4)$,

$385-391$.

https://doi.org/10.2307/3344505

Hama, S. (2012). Master class as an effective means of forming professional competence in future teachers of fine arts. Bulletin of Luhansk Taras Shevchenko National University. Pedagogical Sciences, 22(6), 104-110.

Hampsong Foundation. (n.d). Master Classes. With Thomas Hampson and others! Retrieved from https://hampsongfoundation.org/project/m aster-class/

Hanken, I. M. (2010). The benefits of the master class. The masters' perspective. Nordic music pedagogical research. Yearbook, 12, 149-160.

Hanken, I. M. (2015). Listening and learning in a master class. Music Education Research, 17(4), 453-464. https://doi.org/10.1080/14613808.2014.9 30121

Joyce DiDonato. (2019). Teaching. Retrieved from https://joycedidonato.com/activism/teachi ng/

Kirichenko, V. I., \& Kovganych, G. G. (2019). Pedagogy, aimed at the future. Practically oriented manual. Kharkiv: Madrid Printing House. Retrieved from http://lib.iitta.gov.ua/id/eprint/718387

Lomova, E. S. (2018). Master class as a form of training of future teachers of fine arts in the system of their professional training in higher school. Problems of modern pedagogical education, 60(2), 227-229. Retrieved from https://cyberleninka.ru/article/n/masterklass-kak-forma-obucheniya-buduschihpedagogov-izobrazitelnogo-iskusstva-vsisteme-ih-professionalnoy-podgotovki-vvysshey-shkole

Popovych, O (2010). Organization of vocal courses as an innovative form of modern pedagogy. Scientific collections of Lviv National Music Academy named after M. V. Lysenko. Vocal art: history and modernity": coll. Articles, 24, 147-150.

Rotmirova, E.A. (2016). Master class as a way to translate the mechanisms of a successful pedagogical future. Izvestia Saratov
University. New series: Acmeology of education. Developmental Psychology, 2/18(5), 104-109. Retrieved from https://cyberleninka.ru/article/n/masterklass-kak-sposob-translyatsiimehanizmov-uspeshnogopedagogicheskogo-buduschego

Schweitzer, V. (2013, December 13). Delicate Touches Strongly Felt. The New York Times. Retrieved from https://www.nytimes.com/2013/12/15/arts /music/delicate-touches-strongly-felt.html

Stolyarova, I. (n.d.). Voice from the mind. RGMC. Retrieved from http://www.muzcentrum.ru/radioold/programs/recenzii-i-reportazhi/37205golos-ot-uma

Tartini, G. (1913). A letter from the late Signor Tartini to Signora Maddalena Lombardini, (now Signora Sirmen). Published as an important lesson to performers on the violin. (Dr. Burney, Trans.). London: Printed for R. Bremmer by G. Bigg; reprinted by W. Reeves. (Original work published 1779). Retrieved from https://urresearch.rochester.edu/institution alPublicationPublicView.action?institutio nalItemId $=27186 \&$ versionNumber $=1$

The master class media foundation. (n.d.). Our Artists. Retrieved from http://www.masterclassfoundation.org/

Timokhin, V. (1974). Elisabeth Schwarzkopf. Masters of vocal art of the twentieth century, Vol. 1 (pp. 85-110). MosCow: Music.

Thomas Quasthoff. (2020). Master courses. Sharing a secret. The "Quasthoff Method". Retrieved from: https://www.thomasquasthoff.com/en/423-2/.

Walker, A. (1996). Franz Liszt Vol. 3: The Final Years, 1861-1886. New York: Alfred A. Knopf.

Wolf, M. N. (2018). The sophistic education. Leisure, 12(1), 287-296. Retrieved from https://cyberleninka.ru/article/n/sofistiche skoe-obrazovanie/viewer

Zhyshkovych, M. (2018). Master class and its role in generalization and dissemination of performing and pedagogical experience. Problems of Modern Education. Development-Potential-Deficits, 8, 63-71. 